\title{
Antibodies to MOG have a demyelination phenotype and affect oligodendrocyte cytoskeleton \\ OPEN
}

Russell C. Dale, PhD*

Esther M. Tantsis,

MBBS*

Vera Merheb, BSc

Raani-Yogeeta A.

Kumaran, BMedSc

Nese Sinmaz, BSc

Karrnan Pathmanandavel,

MBBS

Sudarshini Ramanathan,

FRACP

David R. Booth, PhD

Louise A. Wienholt, PhD

Kristina Prelog, FRACP

Damien R. Clark, FRACP

Gilles J. Guillemin, PhD

Chai K. Lim, PhD

Emily K. Mathey, PhD

Fabienne Brilot, PhD

Correspondence to

Dr. Brilot:

Fabienne.brilot@sydney.edu.au

Supplemental data at Neurology.org/nn

\section{ABSTRACT}

Objective: To examine the clinical features of pediatric CNS demyelination associated with positive myelin oligodendrocyte glycoprotein (MOG) antibodies and to examine the functional effects of MOG antibody on oligodendrocyte cytoskeleton.

Methods: We measured MOG antibody using a fluorescence-activated cell sorting live cell-based assay in acute sera of 73 children with CNS demyelination (DEM) (median age 8 years, range 1.3-15.3) followed for a median of 4 years. We used MO3.13 cells to examine immunoglobulin (lg) $\mathrm{G}$ effects on oligodendrocyte cytoskeleton using 3D deconvolution imaging.

Results: MOG antibodies were found in 31/73 patients with DEM (42\%) but in 0/24 controls. At first presentation, MOG antibody-positive patients were more likely to have bilateral than unilateral optic neuritis (ON) (9/10 vs $1 / 5$, respectively, $p=0.03)$, less likely to have brainstem findings (2/31 vs $16 / 42, p=0.005)$, more likely to have a raised erythrocyte sedimentation rate $>20 \mathrm{~mm} / \mathrm{h}$ (9/19 vs $3 / 21, p=0.05)$, less likely to have intrathecal oligoclonal bands (0/16 vs 5/27, $p=0.18$ ), and less likely to be homozygous or heterozygous for human leukocyte antigen DRB1*1501 (3/18 vs 7/22, $p=0.46$ ). $M O G$ antibody positivity varied according to clinical phenotype, with $O N$ and relapsing $O N$ most likely to be seropositive. Two relapsing MOG antibody-positive patients treated with mycophenolate mofetil remain in remission and have become MOG antibody seronegative. Oligodendrocytes incubated with purified IgG from MOG antibody-positive patients showed a striking loss of organization of the thin filaments and the microtubule cytoskeleton, as evidenced by F-actin and $\beta$-tubulin immunolabelings.

Conclusions: MOG antibody may define a separate demyelination syndrome, which has therapeutic implications. MOG antibody has functional effects on oligodendrocyte cytoskeleton. Neurol Neuroimmunol Neuroinflammation 2014;1:e12; doi: 10.1212/NXI.0000000000000012

\section{GLOSSARY}

ADEM = acute disseminated encephalomyelitis; AQP4 = aquaporin-4; CIS = clinically isolated syndrome; DEM = demyelinating diseases; ESR = erythrocyte sedimentation rate; $\mathbf{F A C S}=$ fluorescence-activated cell sorting; $\mathbf{H C}=$ healthy control; $\mathbf{H E K}=$ human embryonic kidney; $\mathbf{H L A}=$ human leukocyte antigen; $\mathbf{I} \mathbf{g}=$ immunoglobulin; $\mathbf{M B P}=$ myelin basic protein; $\mathbf{M M F}=$ mycophenolate mofetil; $\mathbf{M O G}=$ myelin oligodendrocyte glycoprotein; $\mathbf{M S}=$ multiple sclerosis; $\mathbf{N M O}=$ neuromyelitis optica; $\mathbf{O N}=$ optic neuritis; SNP $=$ single nucleotide polymorphism; $\mathbf{T M}=$ transverse myelitis

Recently, autoantibodies that bind to cell surface antigens have been shown to be important diagnostic biomarkers in autoimmune brain disease, including autoimmune encephalitis and autoimmune demyelination. ${ }^{1-3}$ Myelin oligodendrocyte glycoprotein (MOG) is a minor component of myelin proteins but has been the focus of extensive research in demyelinating diseases. MOG is localized on the outermost surface of myelin and has a proposed role in the regulation

\footnotetext{
*These authors contributed equally to the manuscript.

From the Neuroimmunology Group (R.C.D., E.M.T., V.M., R.-Y.A.K., N.S., K. Pathmanandavel, S.R., F.B.), Institute for Neuroscience and Muscle Research, The Kids Research Institute at the Children's Hospital at Westmead, Sydney Medical School, University of Sydney, Westmead, Australia; Institute for Immunology and Allergy Research (D.R.B.), Westmead Millenium Institute for Medical Research, University of Sydney, Westmead, Australia; Clinical Immunology (L.A.W.), Royal Prince Alfred Hospital, Sydney Medical School Immunology \& Infectious Diseases, University of Sydney, Camperdown, Australia; Department of Radiology (K. Prelog), the Children's Hospital at Westmead, Australia; Department of Paediatric Neurology (D.R.C.), Women's and Children's Hospital, North Adelaide, Australia; Neuroinflammation Group (G.J.G., C.K.L.), MND and Neurodegenerative Diseases Research Centre, Macquarie University, Australian School of Advanced Medicine, North Ryde, Australia; and Neuroinflammation Group (E.K.M.), Brain and Mind Research Institute, University of Sydney, Camperdown, Australia.

Go to Neurology.org/nn for full disclosures. Funding information and disclosures deemed relevant by the authors, if any, are provided at the end of the article. The Article Processing Charge was paid by the authors.

This is an open access article distributed under the terms of the Creative Commons Attribution-Noncommercial No Derivative 3.0 License, which permits downloading and sharing the work provided it is properly cited. The work cannot be changed in any way or used commercially.
} 
of microtubule stability. ${ }^{4}$ Autoantibodies against MOG (MOG antibodies) have been shown to mediate demyelination in rodents in "2-hit models" and also in primates. . $^{5-8}$

The importance of MOG antibodies in human demyelinating disease has previously been controversial, predominantly due to the use of antibody assays that denature protein and alter conformation. More recently, using cell-based assays, high titer MOG antibody has been unequivocally found in $20 \%-40 \%$ of children with acute CNS demyelination. ${ }^{9}$ In particular, MOG antibodies have been shown to be associated with acute disseminated encephalomyelitis (ADEM) and patients with neuromyelitis optica (NMO)-like phenotypes who are negative for NMO immunoglobulin (Ig) G. ${ }^{10-16} \mathrm{How}^{-}$ ever, detailed clinical and radiologic phenotyping associated with MOG antibodies is still lacking, and the role of MOG antibodies as a biomarker in clinical practice is still not clear.

Herein, we further define the clinical significance of MOG antibody as a biomarker and show that MOG antibody can modify the microtubule network and thin filaments of oligodendrocytes.

METHODS Patients and controls. Patients. The stored acute serum $\left(-80^{\circ} \mathrm{C}\right)$ taken from 73 children during their first episode of CNS demyelination (DEM) was used for this study (median age 8 years, range 1.3-15.3, 37 females). All sera were acute and before immune therapy. The clinical and radiologic features of 60 of the patients have been reported previously, ${ }^{17}$ but the serologic investigation of this cohort has not been previously reported. The patients were clinically phenotyped using 2013 consensus criteria. ${ }^{18}$ The first episode of demyelination was $\operatorname{ADEM}(\mathrm{n}=28)$, transverse myelitis $(\mathrm{TM}, \mathrm{n}=15)$, optic neuritis ( $\mathrm{ON}, \mathrm{n}=15)$, and other clinically isolated syndrome (CIS) excluding TM and ON $(\mathrm{n}=15)$. These other CIS patients had polyfocal CIS, cerebellar CIS, brainstem CIS, or hemispheric CIS. The acute MRI brain scans $(\mathrm{n}=70)$ and MRI spine $(\mathrm{n}=30)$ were reviewed and rated using MRI criteria blinded to the laboratory findings, as previously described using McDonald, KIDMUS, Callen, and Verhey criteria. ${ }^{17}$ The patients were followed for a median of 4.0 years (range 0.3 13.7 years). At study census and classification, 54 patients had a monophasic disease (ADEM $\mathrm{n}=24, \mathrm{TM} \mathrm{n}=13, \mathrm{ON} \mathrm{n}=7$, "other CIS" $\mathrm{n}=10$ ). Nineteen of 73 patients had a relapsing demyelinating disorder (multiple sclerosis [MS $] \mathrm{n}=15$, relapsing $\mathrm{ON} n=4)$. The 15 patients with MS fulfilled criteria by Krupp et al. ${ }^{18}$ and had 2 or more clinical events.

Controls. We have previously shown that MOG antibodies are specific to CNS demyelination. ${ }^{10}$ To generate a control range for this study, 24 pediatric controls with other neurologic disease, including epilepsy, cerebral palsy, neurometabolic disease, and neurodegenerative disorders, were used (median age 11 years, range $2-14)$.
Patient and control sera had IgG concentrations measured by nephelometry (BN ProSpec, Siemens, Germany), and IgG values were within the normal range $(6.2-14.4 \mathrm{~g} / \mathrm{L})$.

CSF samples $(n=20$ controls and $n=22$ demyelinating disorders) were taken at acute presentation at the same time as sera.

Standard protocol approvals, registrations, and patient consents. Ethics approval for this study was granted by the Sydney Children's Hospitals Network Human Ethics Committee (12/SCHN/395, SSA/12/SCHN/398, 08/CHW/108, 09/ $\mathrm{CHW} / 56, \mathrm{SSA} / 09 / \mathrm{CHW} / 143)$, and written informed consent was obtained from patients.

Cloning and expression of human MOG. Human full-length MOG cDNA were cloned from a fetal brain RNA library (gift from Dr. Monkol Lek). Sequence-verified MOG cDNA was subcloned into PIRES2-ZsGreen 1 lentivirus vector, enabling both MOG and ZSGreen to be coexpressed in cells separately (gift from Dr. Stuart Turville). We used published protocols to transduce and obtain MOG-expressing human embryonic kidney 293 cells $\left(\mathrm{HEK} 293^{\mathrm{MOG}+}\right)$ and oligodendroglial $\left(\mathrm{MO} 3.13^{\mathrm{MOG}+}\right)$ cells. $^{19}$ Control cells (HEK293 $3^{\mathrm{Ct}}$ and MO3.13 ${ }^{\mathrm{Ct}}$ cells) were obtained by transduction by particles with empty pIRES2-ZSGreen vectors. We used HEK293 $3^{\mathrm{MOG}+}$ cells for the MOG antibody assay to conform to recent reports and $\mathrm{MO} 3.13^{\mathrm{MOG}+}$ cells for functional studies due to their oligodendrocyte characteristics. Transduction in both cell lines resulted in 75\%-85\% MOG-expressing cells in culture.

Cell-based assay for detection of antibodies to cell surface MOG in serum and CSF. We used fluorescence-activated cell sorting (FACS) analysis to detect antibody binding of patient serum IgG to surface MOG transduced in HEK293 cells as we have previously described (appendix e-1 at Neurology.org/nn). ${ }^{10,20-23}$ Samples were considered positive if they were above threshold at least 2 times out of 3 repeated experiments, and the intra-assay variation is summarized in appendix e- 1 .

ELISA assay for detection of antibodies to aquaporin- 4 antibody in serum. Serum samples were tested with an aquaporin-4 (AQP4) autoantibody ELISA kit according to the manufacturer's instructions (RSR Limited, Pentwyn, Cardiff, United Kingdom).

Functional effects on human oligodendroglial cells. MO3.13 cell line is an immortal human-human hybrid cell line that expresses phenotypic characteristics of primary oligodendrocytes and was created by fusing a 6-thioguanine-resistant mutant of the human rhabdomyosarcoma RD (cancer of skeletal muscle) with adult human oligodendrocytes by a lectin-enhanced polyethylene glycol procedure. ${ }^{24}$ Transduced human oligodendroglial MO3.13 $3^{\mathrm{MOG}+}$ and $\mathrm{MO} 3.13^{\mathrm{Cll}}$ cells were cultured as previously described ${ }^{24}$ and were immunostained with described protocols (appendix e-1).22,23 We purified human IgG or human MOG IgG from human sera using protein G-agarose and Microcon (Millipore, Billerica, MA), and human MOG bound to an activated N-hydroxysuccinimide agarose column (GE Healthcare, Little Chalfont, United Kingdom). ${ }^{25,26}$ We also immunoabsorbed MOG antibody-positive sera by incubating 6 wells of live HEK293 $3^{\mathrm{MOG}+\mathrm{Cd}}$ cells with MOG antibody-positive and -negative sera. ${ }^{22}$ In order to visualize effects of protein G-purified human IgGs on single cells, MO3.13 cells were seeded at low density and incubated with $6 \mu \mathrm{g}$ of protein G-purified human IgGs from patient or control sera and HEK293 $3^{\mathrm{MOG}+}$ immunoabsorbed MOG antibody-positive serum for 45 minutes at room temperature followed by goat anti-human $\operatorname{IgG}$ secondary antibody for 15 minutes at room temperature. ${ }^{27,28} \mathrm{After}$ washing, cells were fixed and permeabilized, and cytoskeleton filamentous actin (F-actin, marker of cytoskeleton thin filaments) and $\beta$-tubulin 
(marker of cytoskeleton microtubule) were quantified using 3D deconvolution microscopy (detailed methodology in appendix e-1). ${ }^{29}$

Human leukocyte antigen DRB1*1501 genotyping. DNA from patients with DEM $(\mathrm{n}=40)$ was extracted from saliva using a saliva-specific DNA extraction kit according to the manufacturer's instructions (Oragene, DNA Genotek, Kanata, Ontario, Canada). The rs9271366 single nucleotide polymorphism (SNP) that lies on chromosome 6 at position 32,694,832 upstream of the allelic variation $(A \rightarrow G)$ was used to genotype the patients for human leukocyte antigen (HLA)-DRB $1 * 1501 .{ }^{30}$ Patients with the allelic $\mathrm{A}$ are negative for HLA-DRB1*1501, whereas patients with the allelic G are HLADRB1*1501-positive. The SNP rs9271366 is always inherited with the HLA-DRB1*1501 allele (complete linkage disequilibrium with HLA-DRB1*1501). ${ }^{30}$ DNA was amplified using PCR (detailed methodology in appendix e-1), and sequences were analyzed by the software Sequencher (Gene Codes Corporation, Ann Arbor, MI).

Statistical analysis. Chi-square with Yates correction test was used to compare MOG antibody positivity between patient and control groups and between patient subgroups, and to compare binary clinical and radiologic features between MOG antibody-positive and negative groups. Wilcoxon 2-sample test was used to compare ages of patients in 2 groups. No adjustment for multiple testing has been performed. The effects of IgG on F-actin and $\beta$-tubulin were normally distributed; thus, means and SDs were analyzed with the 2-tailed Student $t$ test. A $p$ value less than 0.05 was considered significant for the 2-tailed Student $t$ test (MOG antibody pathogenic effect).

RESULTS Surface MOG IgG antibody in children with demyelinating diseases. In order to align our detection method to recent reports, we first detected MOG antibody in serum using FACS assay and HEK cells expressing human MOG. ${ }^{11,14,16,31,32}$ The mean fluorescence intensity correlated with antibody concentration (figure 1A). Using the mean plus 3 SDs to establish the threshold for positivity, MOG antibodies were found in $31 / 73(42 \%)$ of the DEM group but in $0 / 24$ controls (figure $1, \mathrm{~B}-\mathrm{D}, p=0.000$ ). We have tested 57 other medical and neurologic controls, and all were negative. We also tested MOG antibody in CSF (figure 1E). We had CSF available in 22 patients with DEM, of which 5 were positive for MOG antibody in serum. Only 3/22 CSF samples were positive, 2 of which were serum positive and 1 of which was serum negative (figure 1E). Serologic testing for AQP4 antibodies was performed in 64 patients with DEM and was negative in all (data not shown).

Clinical and investigation findings according to serum MOG antibody findings. First episode. We compared the clinical features according to MOG antibody status during the first episode of demyelination in detail, and findings are presented in table e- 1 . Patients with positive MOG antibody were younger (median age 6.7 vs 10.4 years, $p=0.06$ ) and marginally more likely to be female $(18 / 31,58 \%$ vs $19 / 42,45 \%, p=0.40)$. MOG antibody positivity was negatively associated with brainstem signs (2/31 vs $16 / 4242, p=0.005)$. In patients with $\mathrm{ON}$, positive MOG antibody was more common in patients with bilateral compared to unilateral $\mathrm{ON}$ ( $9 / 10$ vs $1 / 5$, respectively, $p=0.03$ (figure 1 F). MOG antibody-positive patients were more likely to have a raised erythrocyte sedimentation rate (ESR) $>20 \mathrm{~mm} / \mathrm{h}$ during the first episode than MOG antibody-negative patients ( $9 / 19$ vs $3 / 21, p=0.05$ ) There was no correlation between age and elevated ESR in MOG antibody-positive patients (figure 1G). Intrathecal oligoclonal bands were not present in the MOG antibody-positive patients and were seen only in MOG antibody-negative patients (0/16 vs $5 / 27$, $p=0.18)$. MOG antibody-positive patients were less likely to be homozygous or heterozygous for HLA$\mathrm{DRB}^{*} 1501$ than patients with negative MOG antibody $(3 / 18,17 \%$ vs $7 / 22,32 \%, p=0.46)$. Detailed blinded radiologic analysis of MRI brain $(\mathrm{n}=70)$ and MRI spine $(\mathrm{n}=30)$ during the first episode showed no significant differences according to MOG antibody status (table e-2). There was no difference in MRI MS criteria using McDonald, KIDMUS, Callen, and Verhey (table e-3).

Follow-up diagnosis. To compare MOG antibody findings, we compared the subgroups according to classification at follow-up (figure 1, H and I). In the monophasic subgroups, MOG antibodies were positive in 11/24 (46\%) patients with ADEM, 6/7 (86\%) patients with $\mathrm{ON}, 4 / 13(31 \%)$ patients with TM, and $0 / 10$ (0\%) patients with "other CIS" (defined in Methods). Patients with monophasic ON were more likely to be MOG antibody-positive than the rest of the cohort (6/7 vs 25/66, $p=0.04)$, and patients with "other CIS" were less likely to be MOG antibody-positive than the rest of the cohort $(0 / 10$ vs $31 / 63, p=$ $0.01)$. In the relapsing patients, MOG antibody was positive in $7 / 15(47 \%)$ of patients with MS and $3 / 4$ (75\%) patients with relapsing ON. It is interesting that the 3 MOG antibody-positive patients with relapsing $\mathrm{ON}$ were negative for AQP4 antibody, whereas the MOG antibody-negative patient with relapsing $\mathrm{ON}$ was not tested for AQP4 antibody due to insufficient serum. In the relapsing patients $(n=19)$, the MOG antibody-positive patients were younger (median 5.6 years, range 2.6-14.2) than the -negative patients (median 12.9 years, range $2.5-15.3, p=0.03$ ). The MOG antibody-positive patients had fewer relapses (22 relapses in 60.3 patient-years, median annualized relapse rate 0.56 ) than the MOG antibody-negative patients (26 relapses in 39 patient-years, median annualized relapse rate 0.65 ).

Longitudinal MOG antibody in 2 patients treated with immune suppression. Two recent patients (figure 2 and appendix e-2) with positive MOG antibodies who fulfilled 2013 criteria for $\mathrm{MS}^{18}$ were treated with mycophenolate mofetil (MMF), which produced clinical remission, no new lesions on follow-up MRI scans, 
A

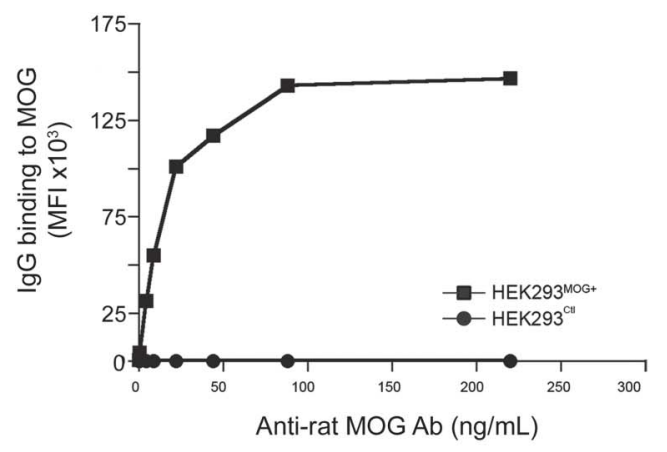

D

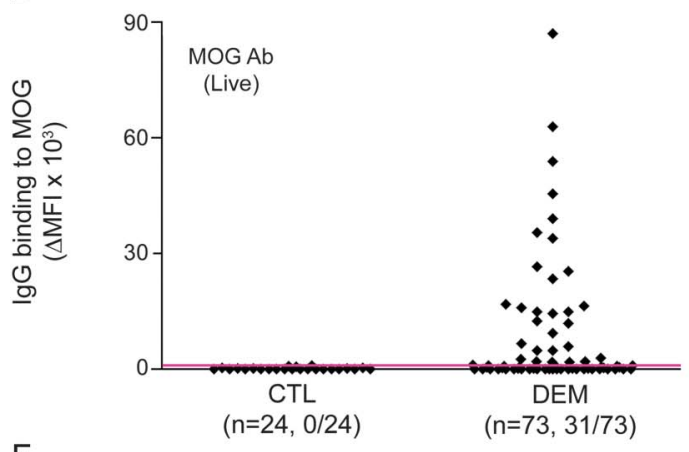

$\mathrm{F}$
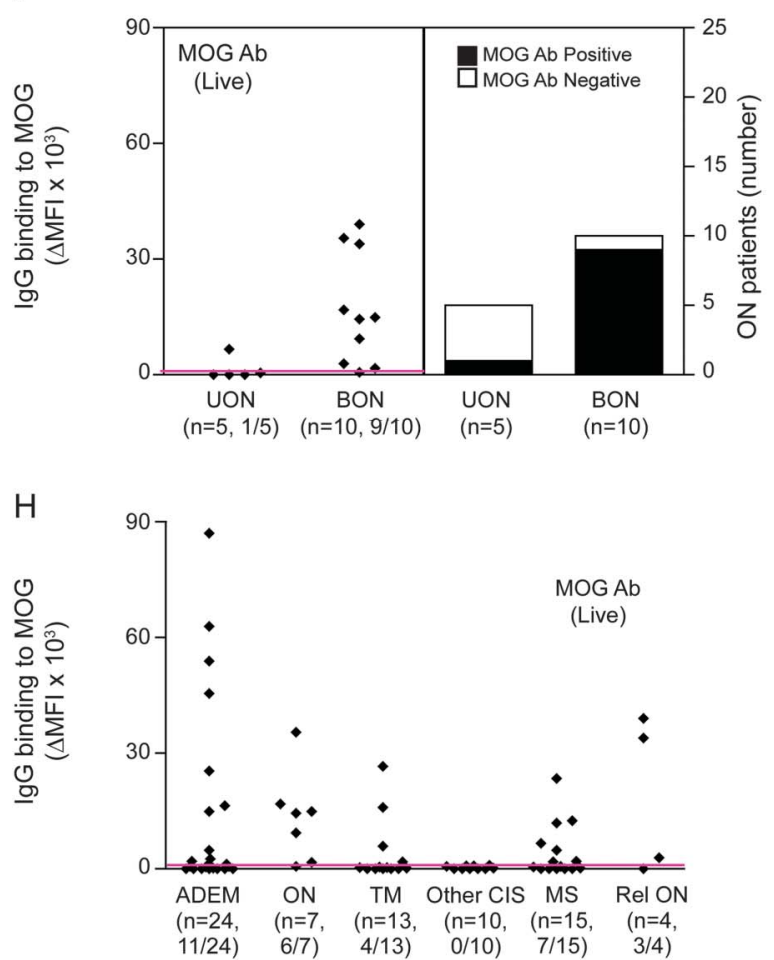

B

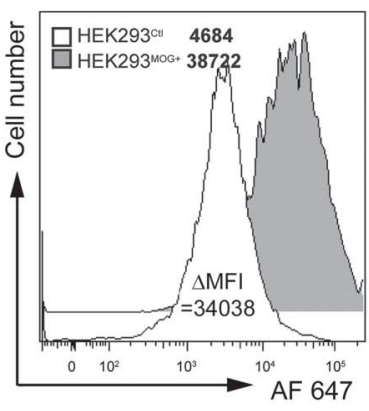

C

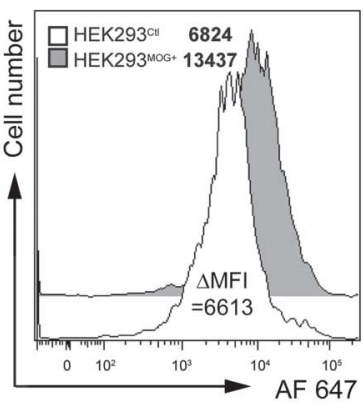

E

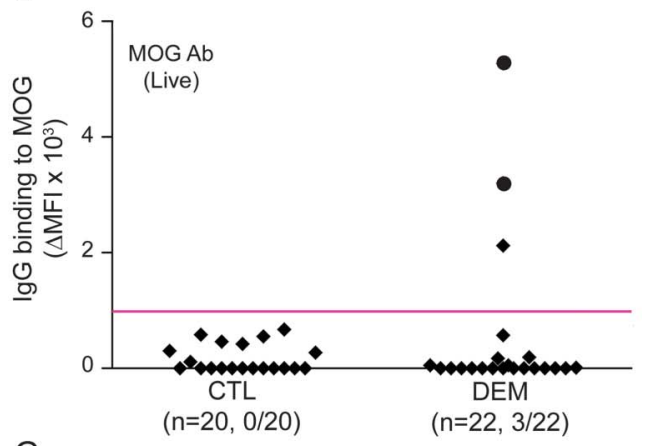

G

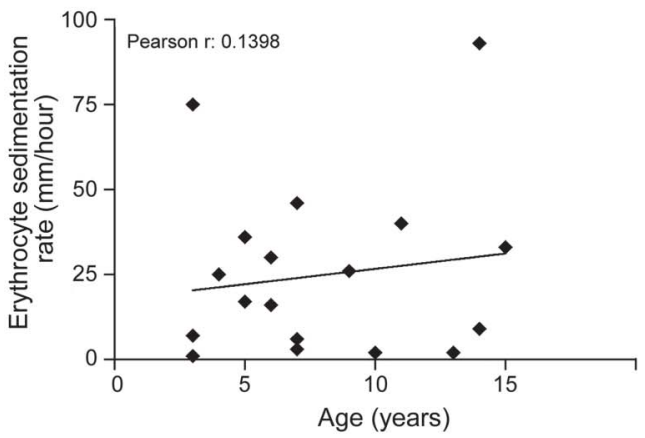

।

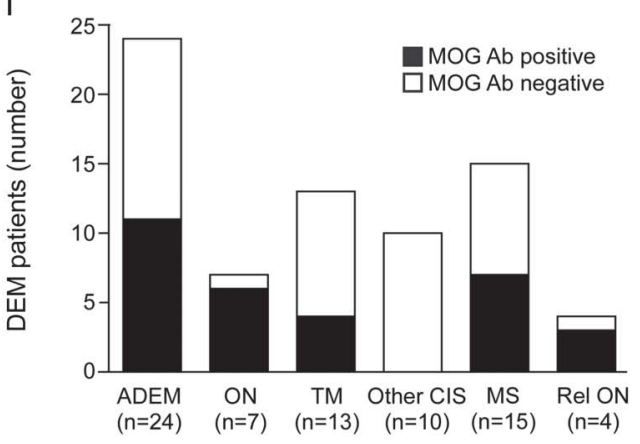

(A) Antibody reactivity to myelin oligodendrocyte glycoprotein (MOG) was determined by flow cytometry live cell-based assay. (B) Representative example of flow cytometry histograms for one MOG antibody-positive patient with a very high $\triangle \mathrm{MFI}$ and (C) an intermediate $\triangle \mathrm{MFI}$. MFI values are noted in the legend. (D) Human surface MOG IgG antibody was detected in 31/73 sera from patients with demyelinating diseases (DEM) and 0/24 controls (CTL). Magenta line on graph represents the positivity threshold. MOG antibody positivity is shown between brackets. (E) Surface MOG antibody was detected in $3 / 22$ CSF from patients with DEM and 0/20 CSF from patients with other neurologic diseases (CTL). Black circles represent patients with positive MOG antibody in CSF and in serum. (F) Distribution and number of MOG antibody-positive patients in optic neuritis (ON). (G) Correlation between erythrocyte sedimentation rate and age in MOG antibody-positive patients. (H) Distribution and (I) number of MOG antibody-positive patients in demyelinating diseases at follow-up. Ab = antibody; $\mathrm{ADEM}=$ acute disseminated encephalomyelitis; $\mathrm{CIS}$ = clinically isolated syndrome; $\mathrm{BON}=$ bilateral optic neuritis; $\mathrm{HEK}=$ human embryonic kidney; Ig = immunoglobulin; MFI = mean fluorescence intensity; MS = multiple sclerosis; TM = transverse myelitis; UON = unilateral optic neuritis. 


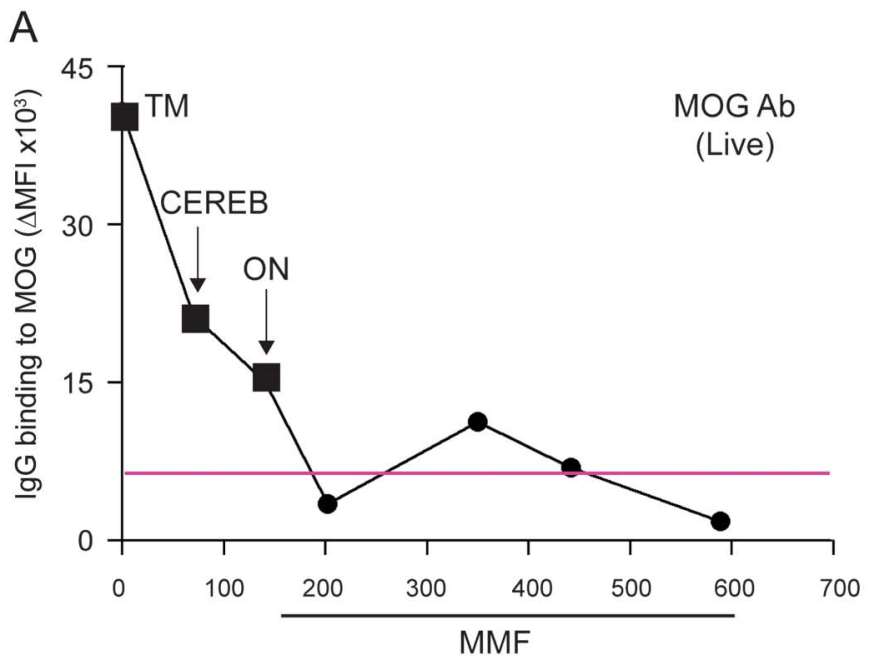

Time elapsed after first episode of demyelination (days)

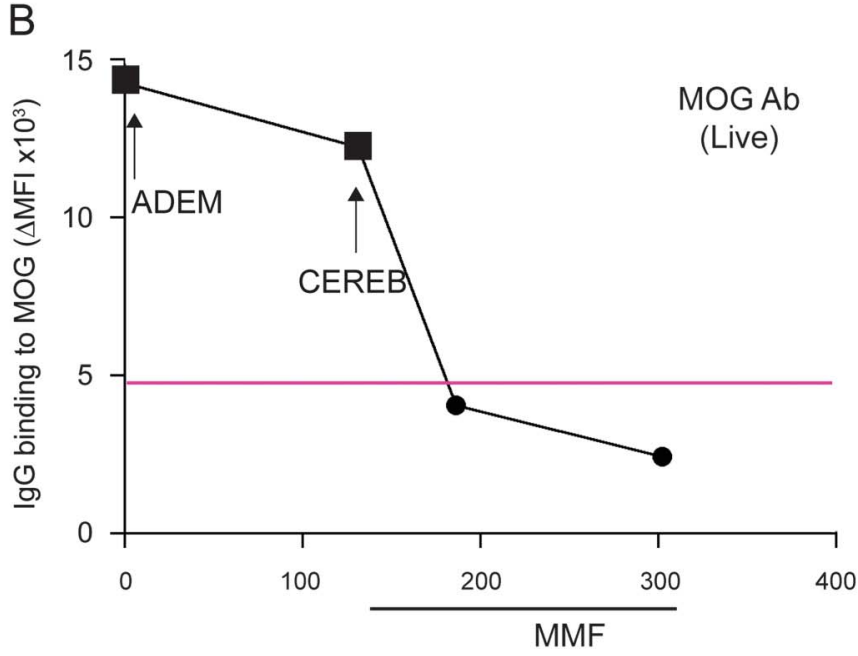

Time elapsed after first episode of demyelination (days)
C

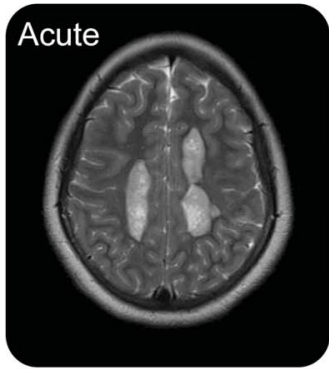

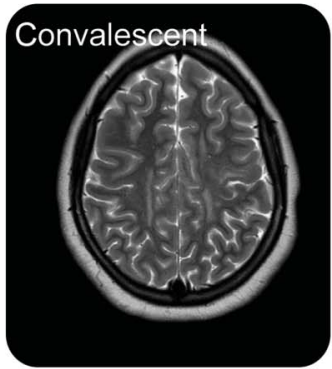
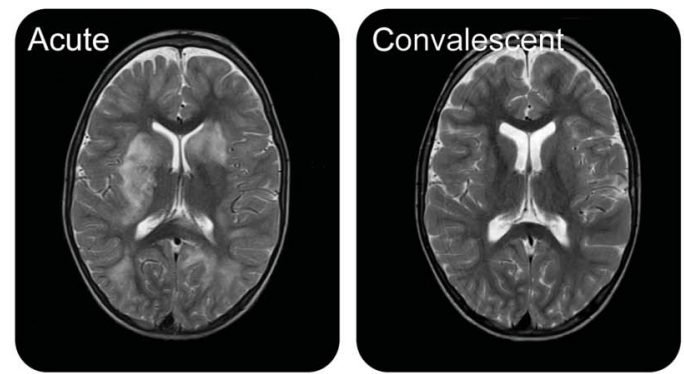

In both patient $A(A)$ and patient $B(B)$, upon treatment mycophenolate mofetil (MMF), myelin oligodendrocyte glycoprotein (MOG) antibody decreased to within the healthy control range (below threshold of positivity), and these low titers were associated with remission. Representative dot plot out of 3 experiments is shown. Magenta lines on graphs represent the positivity threshold (obtained with 24 control samples). Black squares represent serum analysis during acute demyelination episodes, and black circles represent sera during remission. Type of demyelinating episode is shown on graph. (C, D) Representative T2 axial MRI scans demonstrate demyelinating lesions during the first acute event and during convalescence. Patient $A(C)$ had globular deep white matter lesions on acute scan (left panel), which show residual gliosis on convalescent scan and no new lesions (right panel). Patient $B$ (D) had inflammatory lesions in basal ganglia and white matter on acute scan (left panel), with complete resolution on convalescent scan and no new lesions (right panel). Ab = antibody; $\mathrm{ADEM}$ = acute disseminated encephalomyelitis; $\mathrm{CEREB}=$ cerebellar episode; lg = immunoglobulin; MFI = mean fluorescence intensity; ON = optic neuritis; $\mathrm{TM}=$ transverse myelitis.

and normalization of MOG antibodies (figure 2 and appendix e-2). In both patients, upon treatment with MMF, MOG antibody decreased below the threshold of positivity (figure $2, \mathrm{~A}$ and $\mathrm{B}$ ).

Loss of cytoskeleton organization by MOG antibody or purified IgG from children with demyelinating diseases. Human oligodendrocyte MO3.13 ${ }^{\mathrm{MOG}+}$ cells expressed MOG at their surface, whereas no MOG expression was observed on $\mathrm{MO} 3.13^{\mathrm{Cd}}$ cells (figure 3). MO3.13 cells also expressed oligodendrocyte markers, such as $2^{\prime}, 3^{\prime}$ cyclic nucleotide 3' -phosphodiesterase (CNPase), galactocerebroside (GalC), oligodendrocyte marker O4, vimentin, and c-series ganglioside-specific antigen (A2B5) (figure 3A). Myelin basic protein (MBP), a specific marker of mature oligodendrocytes, was observed only in PMA-differentiated MO3.13 $3^{\mathrm{MOG}+}$ cells (figure 3A), suggesting that undifferentiated MO3.13 cells are immature oligodendrocytes. Using purified IgG and immunoaffinity-purified MOG IgG from MOG antibody-positive sera, we immunolabeled HEK293 $3^{\text {MOG }}$ and HEK293 $3^{\mathrm{Cll}}$ cells on live cells by FACS (figure $3 \mathrm{~B}$ ) and on fixed MO3.13 $3^{\mathrm{MOG}+}$ cells by immunocytochemistry (figure 3C) and showed a positive immunostaining compared to MOG antibody-negative sera, suggesting that protein G-purified IgG includes MOG-specific IgG. Due to small volumes of pediatric sera, we used protein G-purified IgG in pathogenic experiments. Next, we treated fixed and live MO3.13 $3^{\mathrm{MOG}+/ \mathrm{Cd}}$ cells with $\mathrm{IgG}$ from MOG antibody-positive and -negative patients with DEM and healthy controls (HCs). Then, all cells were immunolabeled for $\beta$-tubulin (marker of microtubule) or F-actin (marker of thin filaments). We quantified results and expressed them by the F-actin and $\beta$-tubulin relative enrichments in the cytoplasm and perinuclear region over the entire cell. All results were 
Figure 3 Human oligodendroglial МОз.13 MOG-purified human IgG from MOG antibody-positive DEM patients
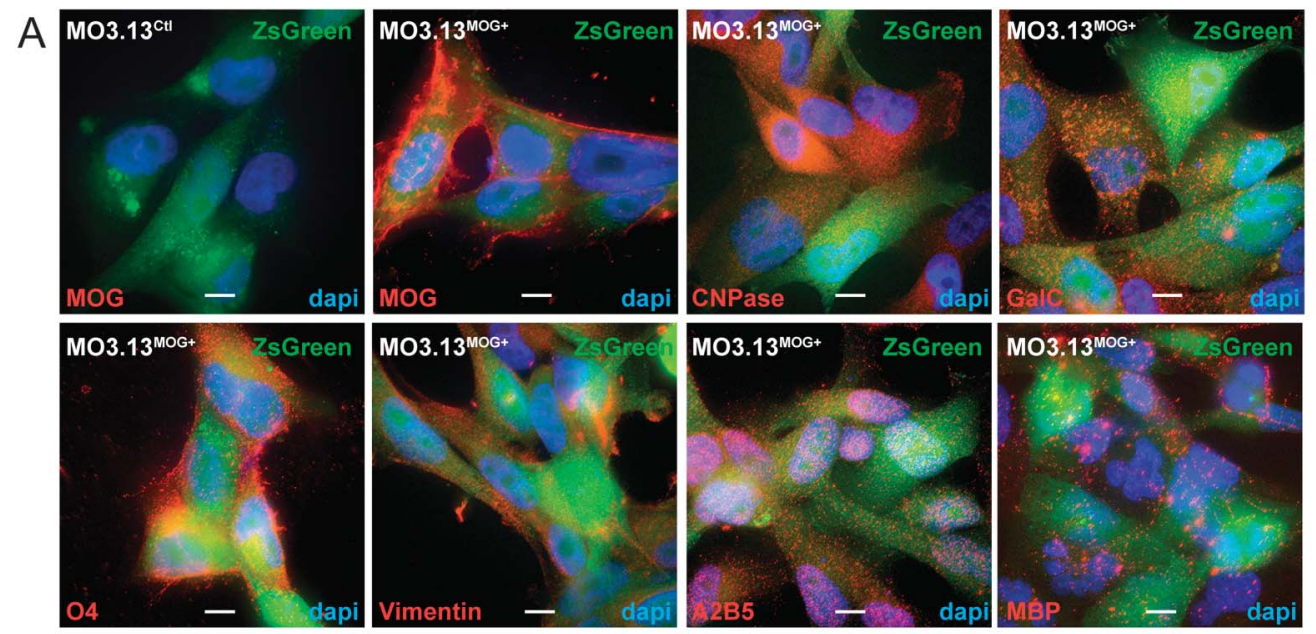

B

Protein G-purified DEM IgG (LIVE)
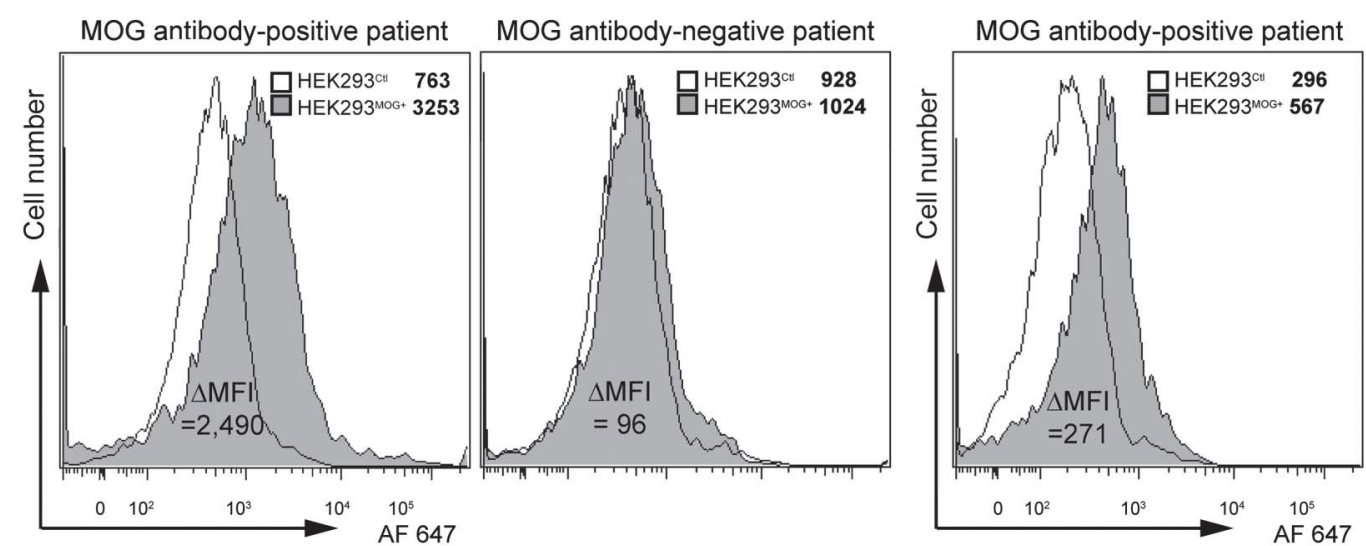

MOG antibody-negative patient

C

Protein G-purified DEM IgG
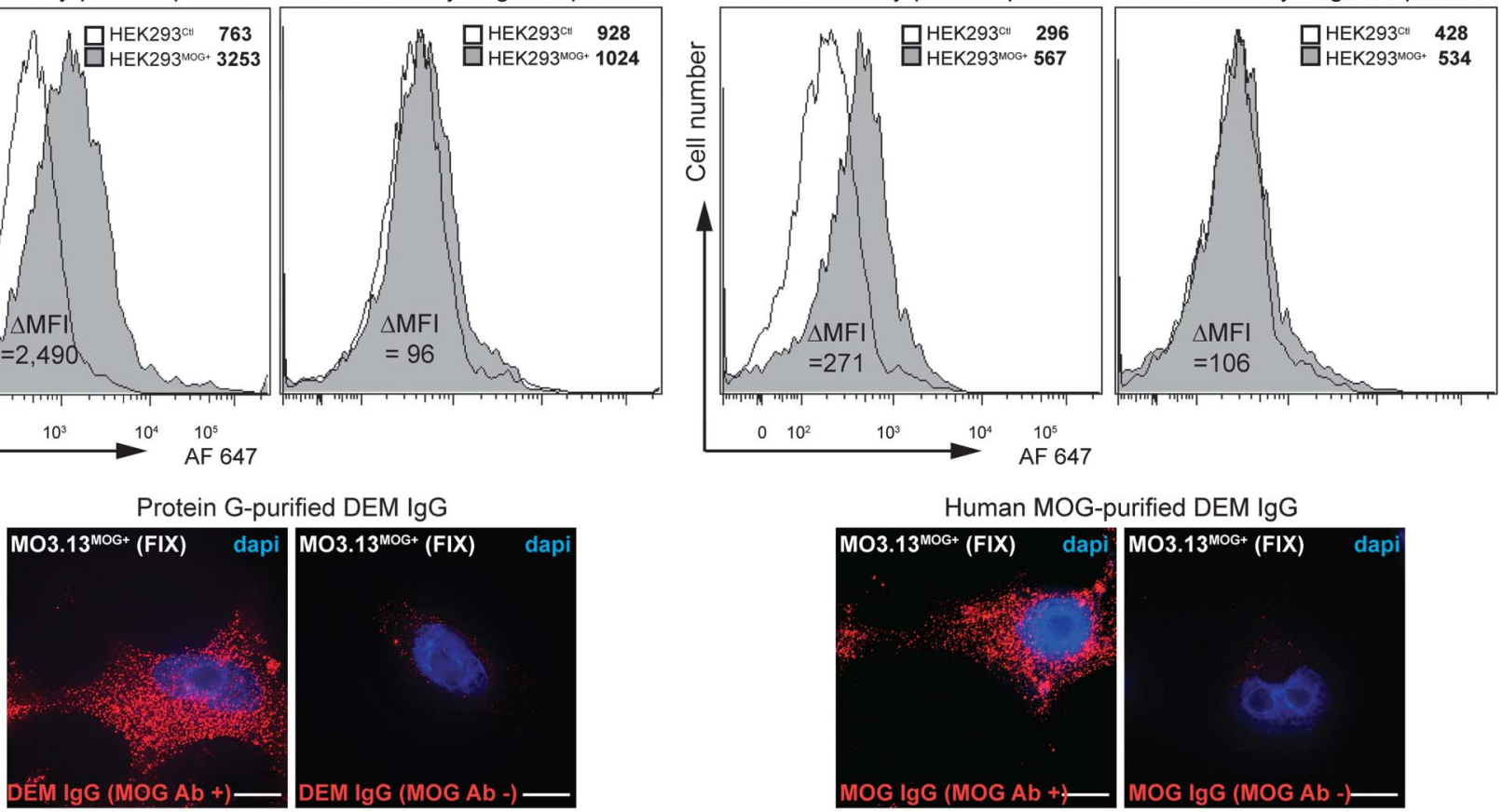

Human MOG-purified DEM IgG

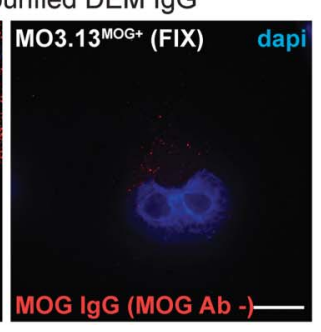

(A) Immunocytochemistry on fixed permeabilized cells showed that MO3.13 ${ }^{\mathrm{MOG}+}$ cells expressed oligodendrocyte markers. (B) Protein G- and human MOGimmunopurified IgG from MOG antibody-positive serum immunolabeled live HEK293 ${ }^{\mathrm{MOG}+}$ cells but did not immunolabel HEK293 ${ }^{\mathrm{Ct}}$ cells compared to MOG antibody-negative serum. Binding to cells was determined by flow cytometry. Mean fluorescence intensity (MFI) values are shown in legends. (C) Protein G- and human MOG-purified IgG from MOG antibody-positive serum also immunolabeled fixed unpermeabilized MO3.13 ${ }^{\text {MOG }}$ cells compared to MOG antibody-negative serum. Representative data are shown (volume projection of entire Z-stack acquired using 3D deconvolution microscopy). Nuclei stained with 4',6-diamidino-2-phenylindole (DAPI). Bar: $10 \mu \mathrm{m}$. A2B5 = c-series ganglioside-specific antigen A2B5; Ab = antibody; CNPase = 2', 3'-cyclic nucleotide $3^{\prime}$-phosphodiesterase; DEM = demyelinating diseases; GalC = galactocerebroside; HEK = human embryonic kidney; lg = immunoglobulin; $\mathrm{MBP}=$ myelin basic protein; MOG = myelin oligodendrocyte glycoprotein; $\mathrm{O} 4$ = oligodendrocyte marker 04 .

normalized using $\mathrm{F}$-actin and $\beta$-tubulin in $\mathrm{HC}$ IgG-treated fixed cells. Organization of the microtubule and thin filament networks was similar in fixed cells incubated with HC $(100 \%$ \pm 10.1 and $100 \% \pm 22.6$, respectively, figure 4 , $\mathrm{A}$ and $\mathrm{C})$ or DEM IgGs $(104.3 \% \pm 11.3$ and $85.8 \% \pm 31.8$, respectively, figure $4, \mathrm{~A}$ and $\mathrm{C})$; there was clear visualization of "stress-fibers" and filopedia after F-actin immunolabeling (figure 4A, upper panels) and bright mesh-like staining spread out through the entire cell after $\beta$-tubulin immunolabeling (figure 4A, lower panels). Live cells treated by HC IgG displayed a small disorganization of F-actin thin filaments $(91 \% \pm 14.4$, 
A
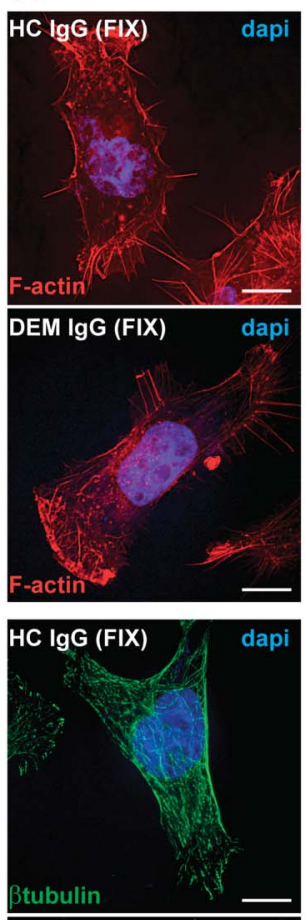

DEM IgG (FIX)

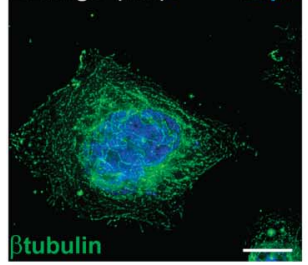

B
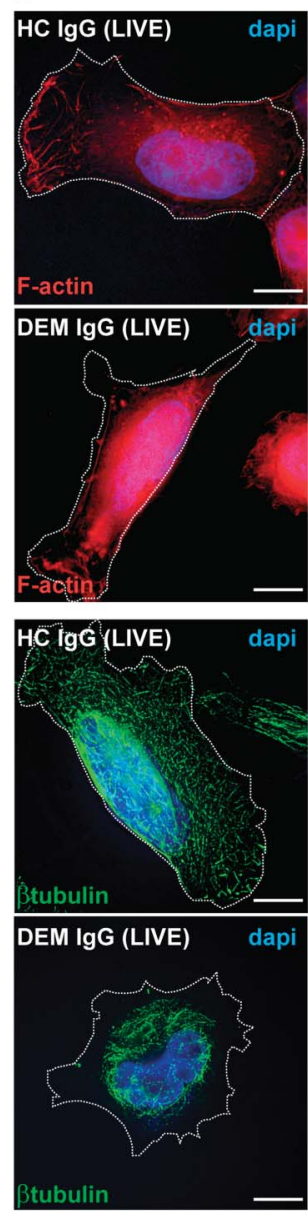

C
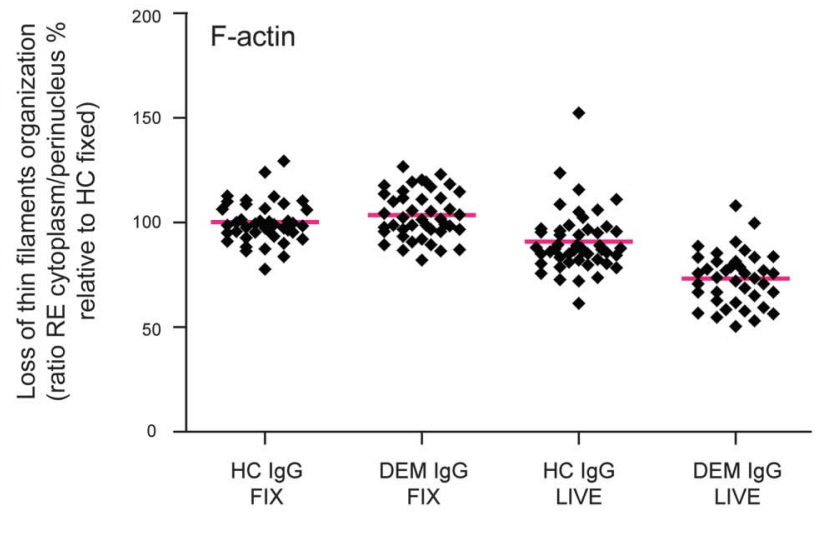
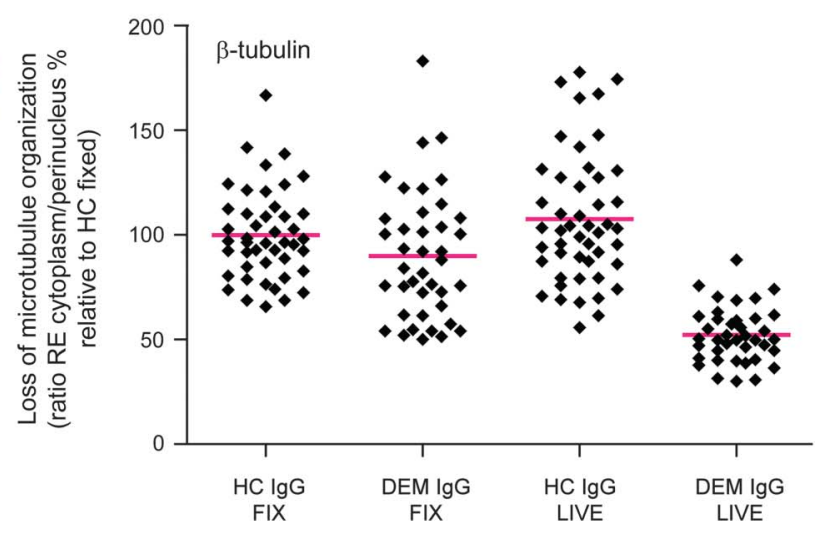

D
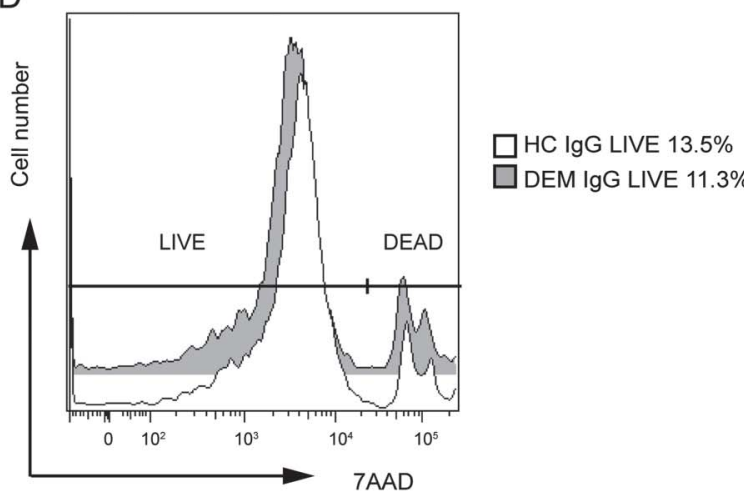

$\square$ DEM IgG LIVE $11.3 \%$

F-actin (upper images) and $\beta$-tubulin (lower images) immunolabelings in human fixed (A) or live (B) oligodendroglial MO3.13 ${ }^{\mathrm{MOG}+}$ cells incubated with purified healthy control (HC) IgG or MOG antibody-positive DEM IgG. Representative data are shown (volume projection of entire Z-stack acquired using deconvolution microscopy). Nuclei stained with 4',6-diamidino-2-phenylindole (DAPI). Bar: $10 \mu \mathrm{m}$. Dotted lines on right images represent contour of cells as determined by differential interference contrast images (not shown). (C) Quantification of change in distribution of thin filament (F-actin, upper scatter plot) and microtubule network ( $\beta$-tubulin, lower scatter plot) organization using 3D deconvolution microscopy. F-actin and $\beta$-tubulin were majorly affected in live cells incubated with DEM lgG. Forty different cells ( 1 cell $=1$ diamond) from $2 \mathrm{HC}$ and $2 \mathrm{DEM}$ patients out of 3 independent experiments are shown. Results are expressed as ratio of the relative enrichment (RE) between cytoplasm and nucleus and values shown are percentages relative to HC IgG FIX (100\%). Red bars represent mean. Note that there also was a loss of organization of the thin filaments after HC IgG incubation on live cells compared to fixed conditions, but to a lesser extent than after DEM IgG. (D) Cell viability assay by flow cytometry on live human oligodendroglial MO3.13 ${ }^{\mathrm{MOG}+}$ cells incubated 45 minutes with $6 \mu \mathrm{g}$ of purified HC IgG or DEM IgG. No difference in cell death was observed. Dead cell percentages are noted in the legend. 7AAD = 7-aminoactinomycin D; DEM = demyelinating diseases; lg = immunoglobulin; MOG = myelin oligodendrocyte glycoprotein. 
$p<0.0001$, figure 4, B and C, upper images) and undisturbed microtubular $\beta$-tubulin network $(107.4 \% \pm 32.1$, figure $4, \mathrm{~B}$ and $\mathrm{C})$, similar to that observed in fixed DEM and HC IgG-treated cells (figure 4A, upper panels). Following treatment with DEM IgG on live MO3.13 $3^{\mathrm{MOG}+}$ cells, we observed a striking loss of organization in both F-actin $(72.4 \%$ $\pm 11.7, p<0.0001$, figure $4, \mathrm{~B}$ and $\mathrm{C})$ and $\beta$-tubulin networks $(52.2 \% \pm 13.1, p<0.0001$, figure $4, \mathrm{~B}$ and $\mathrm{C}$ ) in otherwise healthy-looking undividing cells visualized by differential interference contrast imaging (figure 4B, dotted line, and data not shown) and analyzed by FACS, by which there was no difference in viability between live $\mathrm{MO} 3.13^{\mathrm{MOG}+}$ live cells treated with DEM IgG or HC IgG for 45 minutes (figure $4 \mathrm{D}, 87.2 \pm 0.6$ vs $87.2 \pm 2.11$ ) or 10 hours (data not shown). No loss of cytoskeleton organization was observed when live MO3.13 ${ }^{\mathrm{Cl}}$ cells were incubated with HC IgG and MOG antibodypositive DEM IgG, nor when live MO3.13 $3^{\mathrm{MOG}+}$ cells were incubated with MOG antibody-negative DEM IgG (figure e-1 and appendix e-3). In addition, successful immunoabsorption of MOG antibodypositive serum on $\mathrm{HEK} 293^{\mathrm{MOG}+}$ cells led to no change in cytoskeleton organization when immunoabsorbed serum was incubated on live MO3.13 $3^{\mathrm{MOG}+}$ cells (figure e-1 and appendix e-3). Overall, after incubation with MOG antibodypositive DEM IgG, both F-actin and $\beta$-tubulin immunolabelings appeared to be enriched within a perinuclear region in the center of the cells surrounding the nucleus.

DISCUSSION As in this study, recent reports have consistently found that serum MOG antibody is present in a significant proportion of children with CNS demyelinating disease, whereas AQP4 antibodies are rare. ${ }^{9}$ We believe that the clinical and investigation findings in this report support the evolving concept that MOG antibodies may define a separate autoimmune demyelinating syndrome that may be distinct from classic adult-onset MS. MOG antibodies are present in up to $50 \%$ of children with ADEM, as in this report. Proebstel et al. ${ }^{33}$ found that ADEM MOG antibody seropositive children became seronegative in the recovery period, whereas children with relapsing MS typically remained seropositive. More recently, MOG antibodies have been found in children with $\mathrm{ON}$ and in some patients with NMO phenotype negative for NMO IgG. ${ }^{14,31}$ In this report, we have strengthened this association with $\mathrm{ON}$ and found that patients with bilateral rather than unilateral $\mathrm{ON}$ were more likely to be MOG antibody-positive. Bilateral $\mathrm{ON}$ is a common $\mathrm{ON}$ phenotype in children but is rare in adults, in whom unilateral $\mathrm{ON}$ is the more typical demyelinating event of MS. In contrast, patients with brainstem signs and CIS other than $\mathrm{ON}$ and TM were rarely MOG antibody-positive. An elevated ESR was more common in MOG antibody-positive patients. An elevated ESR is atypical of MS and should raise suspicion of an autoimmune disorder or alternate inflammatory mimic of MS. We showed that elevation of ESR in MOG antibody-positive patients was independent of age. Intrathecal oligoclonal bands are one of the classic biomarkers of MS and were absent in all MOG antibody-positive patients and were present only in the MOG antibody-negative patients. Only 17\% of the MOG antibody-positive patients had 1 or both HLA-DRB1*1501 alleles, the main MS susceptibility allele, which is the same as the previously reported percentage in the "normal" healthy population in Australia, ${ }^{34}$ whereas the MOG antibody-negative patients were more likely to have 1 or more HLADRB1*1501 allele. This negative association was not statistically significant and larger cohorts are required to test whether this correlation is a real rather than a suspected phenomenon. In contrast, radiologic features did not appear to differentiate MOG antibody-positive from -negative patients in this childhood cohort.

The presence of MOG antibodies is unlikely to have therapeutic implications in the first demyelinating event but is more likely to be therapeutically important in the relapsing patient. Although 2 recent patients fulfilled criteria for MS, the presence of MOG antibodies and elevated ESR led us to treat them more like NMO patients with the immune suppression agent MMF rather than conventional MS disease-modifying therapies. Both patients had no clinical or radiologic relapse for 12 months and 36 months, respectively, and both became MOG antibody seronegative. Further studies are required to understand the longitudinal course of patients with MOG antibody-associated relapsing disease and the treatment approach required.

Cell-based assays have been essential to detect MOG antibody with a high specificity, ${ }^{9}$ especially when the full-length MOG is expressed in cells rather than the C-terminal truncated MOG. ${ }^{35}$ Our experience with neuronal antigens informed us that FACS is sensitive and quantitative. ${ }^{10,13,20,22,33,36,37} \mathrm{We}$ detected CSF MOG antibody in only 3 of 22 DEM samples, of which 5 were positive in serum. This suggests CSF is less sensitive than serum for MOG antibody detection, which could be due to a lack of sensitivity or could represent a genuine absence of intrathecal Ig synthesis in these patients. Supporting this concept, none of the patients with positive MOG antibody had intrathecal oligoclonal bands.

The pathogenic function of MOG antibody is still unclear, but over the recent years, the detection of 
MOG antibody against the conformational native form of the antigen has enabled pathogenic studies using native MOG antibody from patient sera. MOG antibodies have been shown to be of the IgG1 isotype, which can activate complement ${ }^{13,16}$ and cell-mediated cytotoxicity, ${ }^{10}$ and induce experimental autoimmune encephalomyelitis in mice. ${ }^{15,38}$ Although the function of MOG is still unclear, MOG has been proposed to stabilize cytoskeletal microtubules. ${ }^{4}$ The monoclonal MOG antibody 818C5 has been shown to induce a rapid $\beta$-tubulin dephosphorylation and invoke a rapid retraction of oligodendrocyte processes, ${ }^{27,28}$ and to alter the cytoskeletal structure and microtubular polymerization after long-term MOG antibody exposure in cultured murine oligodendrocytes. ${ }^{39}$ This effect on $\beta$-tubulin occurred after MOG redistributed over internal MBP domains, independently of F-actin. In our cell model, MBP is only expressed after oligodendrocyte differentiation with phorbol ester, and F-actin was clearly disorganized after incubation with patient Igs, suggesting that there is an MBP-independent microtubular disorganization that would also involve F-actin in our immature oligodendrocyte cell model. We also observed a fast effect after short incubation times that may be due to high expression of surface MOG in transduced cells. Despite the significant alteration in cytoskeleton, no cell death occurred, as previously observed in animal models. Our findings add to the pathogenic potential of MOG antibody, and it is conceivable that different pathogenic effects may be present in different patients. Recent studies have shown that different patients have different epitopes involved in antibody binding that may influence pathogenic properties of MOG antibody. ${ }^{40}$

Taken together, our findings suggest that MOG antibody may define an autoimmune demyelinating syndrome that is clinically and potentially pathologically separate from "classic MS." MOG antibody fulfills criteria as a cell surface autoantibody-associated syndrome and may prove to be a valuable biomarker with therapeutic implications in patients with relapsing demyelinating disorders.

\section{AUTHOR CONTRIBUTIONS}

Study design and conceptualization: R.C.D. and F.B. Drafting of manuscript: R.C.D. and F.B. Acquisition, analysis, and interpretation of results: R.C.D., E.M.T., V.M., R.-Y.A.K., N.S., S.R., K.P., L.A.W., D.R.B., K. Prelog, D.R.C., G.J.G., C.K.L., E.K.M., F.B. Statistical analysis: R.C.D., E.M.T., F.B. Critical revisions of manuscript: R.C.D., E.M.T., V.M., N.S., S.R., K.P., D.R.B., L.A.W., K. Prelog, D.R.C., G.J.G., C.K.L., E.K.M., F.B.

\section{ACKNOWLEDGMENT}

The authors thank all the patients and family members who provided samples for the study. The authors thank Dr. Maggie Wang for use of the Flow Cytometry Core Facility of the Westmead Millennium Institute (Australia). The authors thank Dr. Hong Yu for use of the Imaging Core Facility at the Westmead Research Hub.

\section{STUDY FUNDING}

Supported by the Star Scientific Foundation (Australia), Trish Multiple Sclerosis Research Foundation, Multiple Sclerosis Research Australia, MS Angels Melbourne (Australia), and the Petre Foundation (Australia).

\section{DISCLOSURE}

R.C. Dale has received research funding from the Star Scientific Foundation, the Trish Multiple Sclerosis Research Foundation and Multiple Sclerosis Research Australia, NHMRC, and the Petre Foundation; has received honoraria from Biogen Idec; and is on advisory boards for Queensland Children's Medical Institute Research and MSARD. E.M. Tantsis has received a scholarship from the Australian Postgraduate Award program. V. Merheb and R.-Y.A. Kumaran report no disclosures. N. Sinmaz has received a scholarship from the Australian Postgraduate Award program. K. Pathmanandavel has received a scholarship from the Petre Foundation (Australia). S. Ramanathan has received a scholarship from the National Health and Medical Research Council (Australia). D.R. Booth has received funding from the National Health and Medical Research Council (Australia), the Australian Research Council, Multiple Sclerosis Research Australia, and the Leukemia Foundation; has received honoraria and funding from Biogen Idec, Merck Serono, Sanofi-Aventis, Genzyme, and Pfizer; and is an editor for PLOS ONE; L.A. Wienholt, K. Prelog, and D.R. Clark report no disclosures. G.J. Guillemin is the editor-in-chief for the International Journal for Tryptophan Research and has received research support from the Australian Research Council. C.K. Lim has received research funding from Multiple Sclerosis Research Australia and Trish MS Research Foundation. E.K. Mathey has received funding from the National Health and Medical Research Council (Australia) and the Rebecca L. Cooper Medical Research Foundation (Australia). F. Brilot has received research funding from the Star Scientific Foundation, the Trish Multiple Sclerosis Research Foundation, Multiple Sclerosis Research Australia, MS Angels Melbourne (Australia), and the Petre Foundation; and is an associate editor for the Journal of Visualized Experiments. Go to Neurology.org/nn for full disclosures.

Received February 25, 2014. Accepted in final form April 16, 2014.

\section{REFERENCES}

1. Papadopoulos MC, Verkman AS. Aquaporin 4 and neuromyelitis optica. Lancet Neurol 2012;11:535-544.

2. Vincent A, Bien CG, Irani SR, Waters P. Autoantibodies associated with diseases of the CNS: new developments and future challenges. Lancet Neurol 2011;10:759-772.

3. Wingerchuk DM, Lennon VA, Lucchinetti CF, Pittock SJ, Weinshenker BG. The spectrum of neuromyelitis optica. Lancet Neurol 2007;6:805-815.

4. Johns TG, Bernard CC. The structure and function of myelin oligodendrocyte glycoprotein. J Neurochem 1999;72:1-9.

5. Linington C, Bradl M, Lassmann H, Brunner C, Vass K. Augmentation of demyelination in rat acute allergic encephalomyelitis by circulating mouse monoclonal antibodies directed against a myelin/oligodendrocyte glycoprotein. Am J Pathol 1988;130:443-454.

6. Pollinger B, Krishnamoorthy G, Berer K, et al. Spontaneous relapsing-remitting EAE in the SJL/J mouse: MOG-reactive transgenic T cells recruit endogenous MOG-specific B cells. J Exp Med 2009;206:1303-1316.

7. Schluesener HJ, Sobel RA, Linington C, Weiner HL. A monoclonal antibody against a myelin oligodendrocyte glycoprotein induces relapses and demyelination in central nervous system autoimmune disease. J Immunol 1987; 139:4016-4021.

8. von Budingen HC, Hauser SL, Fuhrmann A, Nabavi CB, Lee JI, Genain CP. Molecular characterization of antibody specificities against myelin/oligodendrocyte glycoprotein in autoimmune demyelination. Proc Natl Acad Sci U S A 2002;99:8207-8212. 
9. Reindl M, Di Pauli F, Rostasy K, Berger T. The spectrum of MOG autoantibody-associated demyelinating diseases. Nat Rev Neurol 2013;9:455-461.

10. Brilot F, Dale RC, Selter RC, et al. Antibodies to native myelin oligodendrocyte glycoprotein in children with inflammatory demyelinating central nervous system disease. Ann Neurol 2009;66:833-842.

11. Di Pauli F, Mader S, Rostasy K, et al. Temporal dynamics of anti-MOG antibodies in CNS demyelinating diseases. Clin Immunol 2011;138:247-254.

12. Lalive $\mathrm{PH}$, Hausler MG, Maurey $\mathrm{H}$, et al. Highly reactive anti-myelin oligodendrocyte glycoprotein antibodies differentiate demyelinating diseases from viral encephalitis in children. Mult Scler 2011;17:297-302.

13. McLaughlin KA, Chitnis T, Newcombe J, et al. Agedependent B cell autoimmunity to a myelin surface antigen in pediatric multiple sclerosis. J Immunol 2009;183: 4067-4076.

14. Rostasy K, Mader S, Schanda K, et al. Anti-myelin oligodendrocyte glycoprotein antibodies in pediatric patients with optic neuritis. Arch Neurol 2012;69:752-756.

15. Zhou D, Srivastava R, Nessler $S$, et al. Identification of a pathogenic antibody response to native myelin oligodendrocyte glycoprotein in multiple sclerosis. Proc Natl Acad Sci U S A 2006;103:19057-19062.

16. Mader S, Gredler V, Schanda K, et al. Complement activating antibodies to myelin oligodendrocyte glycoprotein in neuromyelitis optica and related disorders. J Neuroinflammation 2011;8:184

17. Tantsis EM, Prelog K, Brilot F, Dale RC. Risk of multiple sclerosis after a first demyelinating syndrome in an Australian Paediatric cohort: clinical, radiological features and application of the McDonald 2010 MRI criteria. Mult Scler 2013;19:1749-1759.

18. Krupp LB, Tardieu M, Amato MP, et al. International Pediatric Multiple Sclerosis Study Group criteria for pediatric multiple sclerosis and immune-mediated central nervous system demyelinating disorders: revisions to the 2007 definitions. Mult Scler 2013;19:1261-1267.

19. Aggarwal A, Iemma TL, Shih I, et al. Mobilization of HIV spread by diaphanous 2 dependent filopodia in infected dendritic cells. PLoS Pathog 2012;8:e1002762.

20. Amatoury M, Merheb V, Langer J, Wang XM, Dale RC, Brilot F. High-throughput flow cytometry cell-based assay to detect antibodies to $\mathrm{N}$-methyl-D-aspartate receptor or dopamine-2 receptor in human serum. J Vis Exp 2013; 81:e50935.

21. Brilot F, Merheb V, Ding A, Murphy T, Dale RC. Antibody binding to neuronal surface in Sydenham chorea, but not in PANDAS or Tourette syndrome. Neurology 2011; 76:1508-1513.

22. Dale RC, Merheb V, Pillai S, et al. Antibodies to surface dopamine-2 receptor in autoimmune movement and psychiatric disorders. Brain 2012;135:3453-3468.

23. Mohammad SS, Sinclair K, Pillai S, et al. Herpes simplex encephalitis relapse with chorea is associated with autoantibodies to N-Methyl-D-aspartate receptor or dopamine-2 receptor. Mov Disord 2014;29:117-122.

24. Buntinx M, Vanderlocht J, Hellings N, et al. Characterization of three human oligodendroglial cell lines as a model to study oligodendrocyte injury: morphology and oligodendrocyte-specific gene expression. J Neurocytol 2003;32:25-38
25. Elliott $\mathrm{C}$, Lindner $\mathrm{M}$, Arthur $\mathrm{A}$, et al. Functional identification of pathogenic autoantibody responses in patients with multiple sclerosis. Brain 2012;135:1819-1833.

26. Mathey EK, Derfuss T, Storch MK, et al. Neurofascin as a novel target for autoantibody-mediated axonal injury. J Exp Med 2007;204:2363-2372.

27. Marta CB, Montano MB, Taylor CM, Taylor AL, Bansal R, Pfeiffer SE. Signaling cascades activated upon antibody cross-linking of myelin oligodendrocyte glycoprotein: potential implications for multiple sclerosis. J Biol Chem 2005;280:8985-8993.

28. Marta CB, Taylor CM, Coetzee T, et al. Antibody crosslinking of myelin oligodendrocyte glycoprotein leads to its rapid repartitioning into detergent-insoluble fractions, and altered protein phosphorylation and cell morphology. J Neurosci 2003;23:5461-5471.

29. Brilot F, Strowig T, Roberts SM, Arrey F, Munz C. NK cell survival mediated through the regulatory synapse with human DCs requires IL-15Ralpha. J Clin Invest 2007; 117:3316-3329.

30. Australia and New Zealand Multiple Sclerosis Genetics Consortium (ANZgene). Genome-wide association study identifies new multiple sclerosis susceptibility loci on chromosomes 12 and 20. Nat Genet 2009;41:824-830.

31. Kitley J, Woodhall M, Waters P, et al. Myelin-oligodendrocyte glycoprotein antibodies in adults with a neuromyelitis optica phenotype. Neurology 2012;79:1273-1277.

32. Rostasy K, Mader S, Hennes EM, et al. Persisting myelin oligodendrocyte glycoprotein antibodies in aquaporin- 4 antibody negative pediatric neuromyelitis optica. Mult Scler 2013;19:1052-1059.

33. Probstel AK, Dornmair K, Bittner R, et al. Antibodies to MOG are transient in childhood acute disseminated encephalomyelitis. Neurology 2011;77:580-588.

34. Stewart GJ, Teutsch SM, Castle M, Heard RN, Bennetts BH. HLA-DR, -DQA1 and -DQB1 associations in Australian multiple sclerosis patients. Eur J Immunogenet 1997;24:81-92.

35. Waters P, Woodhall M, Hacohen Y, et al. Antibodies to myelin oligodendrocyte glycoprotein (MOG) in children and adults with demyelinating disorders (NMO). Ann Neurol 2013;74:S18-S19.

36. O'Connor KC, McLaughlin KA, De Jager PL, et al. Selfantigen tetramers discriminate between myelin autoantibodies to native or denatured protein. Nat Med 2007;13:211-217.

37. Waters PJ, McKeon A, Leite MI, et al. Serologic diagnosis of NMO: a multicenter comparison of aquaporin-4-IgG assays. Neurology 2012;78:665-671.

38. Lalive PH, Menge T, Delarasse C, et al. Antibodies to native myelin oligodendrocyte glycoprotein are serologic markers of early inflammation in multiple sclerosis. Proc Natl Acad Sci U S A 2006;103:2280-2285.

39. Dyer CA, Matthieu JM. Antibodies to myelin/oligodendrocytespecific protein and myelin/oligodendrocyte glycoprotein signal distinct changes in the organization of cultured oligodendroglial membrane sheets. J Neurochem 1994; 62:777-787.

40. Mayer MC, Breithaupt C, Reindl M, et al. Distinction and temporal stability of conformational epitopes on myelin oligodendrocyte glycoprotein recognized by patients with different inflammatory central nervous system diseases. J Immunol 2013;191:3594-3604. 


\title{
Neurology ${ }^{\oplus}$ \\ Neuroimmunology \& Neuroinflammation
}

\author{
Antibodies to MOG have a demyelination phenotype and affect oligodendrocyte \\ cytoskeleton \\ Russell C. Dale, Esther M. Tantsis, Vera Merheb, et al. \\ Neurol Neuroimmunol Neuroinflamm 2014;1; \\ DOI 10.1212/NXI.0000000000000012
}

This information is current as of May 22, 2014

Neurol Neuroimmunol Neuroinflamm is an official journal of the American Academy of Neurology.

Published since April 2014, it is an open-access, online-only, continuous publication journal. Copyright $($ ) 2014 American Academy of Neurology. All rights reserved. Online ISSN: 2332-7812.

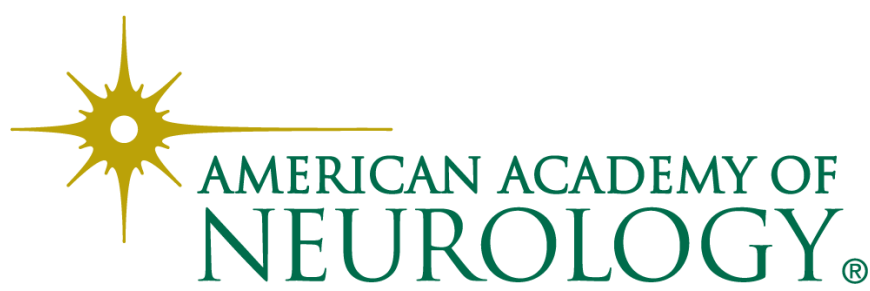




\section{Updated Information \& Services}

\section{Supplementary Material}

\section{References}

Citations

Subspecialty Collections

Permissions \& Licensing

Reprints including high resolution figures, can be found at: http://nn.neurology.org/content/1/1/e12.full.html

Supplementary material can be found at: http://nn.neurology.org/content/suppl/2014/05/22/1.1.e12.DC1

This article cites 40 articles, 10 of which you can access for free at: http://nn.neurology.org/content/1/1/e12.full.html\#\#ref-list-1

This article has been cited by 4 HighWire-hosted articles: http://nn.neurology.org/content/1/1/e12.full.html\#\#otherarticles

This article, along with others on similar topics, appears in the following collection(s):

All Demyelinating disease (CNS)

http://nn.neurology.org//cgi/collection/all_demyelinating_disease_cns All Pediatric

http://nn.neurology.org//cgi/collection/all_pediatric

Autoimmune diseases

http://nn.neurology.org//cgi/collection/autoimmune_diseases

Optic neuritis; see Neuro-ophthalmology/Optic Nerve

http://nn.neurology.org//cgi/collection/optic_neuritis

Information about reproducing this article in parts (figures,tables) or in its entirety can be found online at:

http://nn.neurology.org/misc/about.xhtml\#permissions

Information about ordering reprints can be found online: http://nn.neurology.org/misc/addir.xhtml\#reprintsus

Neurol Neuroimmunol Neuroinflamm is an official journal of the American Academy of Neurology.

Published since April 2014, it is an open-access, online-only, continuous publication journal. Copyright $\odot$ 2014 American Academy of Neurology. All rights reserved. Online ISSN: 2332-7812.

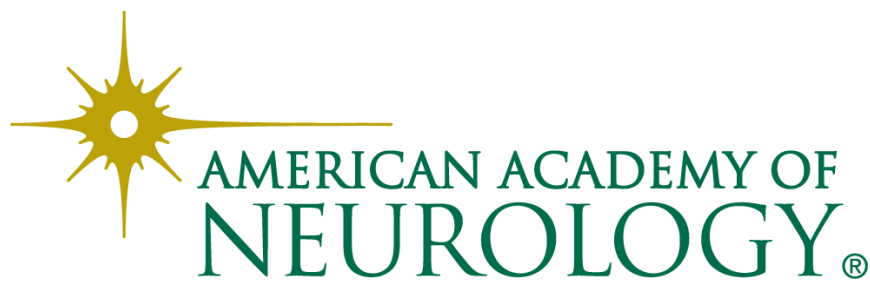

